\title{
Economic Freedom and Research and Development (R\&D): Study based on different income level on developing countries
}

\author{
NurNaddia Nordin ${ }^{1}$; NurHaiza Nordin ${ }^{2}$; Nik Madeeha Nik Mohd Munir ${ }^{2}$ \\ ${ }^{1}$ Department of Economics \\ Faculty of Management and Muamalah \\ Selangor International Islamic University College \\ Bandar Seri Putra, Bangi, Selangor, Malaysia \\ ${ }^{2}$ Department of Business and Finance \\ Faculty of Entrepreneurship and Business \\ University Malaysia Kelantan \\ Kelantan, Malaysia
}

naddia@kuis.edu.my; haiza@umk.edu.my; nmadeehaa@umk.edu.my

\begin{abstract}
This researchs stress on three important issues of economic freedom, domestic and international research and Development (R\&D) and productivity growth by using Panel Dynamic Ordinary Least Square (PDOLS) proposed by Stock and Watson (1993) in estimating 37 selected developing countries that classified based on income level for the time period 2000 to 2010. To encourage domestic and international R\&D activities, host and home countries must have a 'good' institution like economic freedom. The main focus of this study is on economic freedom that we examine the role of economic freedom as a mediating factor of domestic and international R\&D on productivity growth based on different income level on developing countries. The findings indicate that there are mixed results that show positive and negative relationship of the role economic freedom as mediating factor on domestic and international R\&D on productivity growth.
\end{abstract}

Keywords: Economic Freedom, Domestic Research and Development; International Research and Development; Panel Dynamic Ordinary Least Square (P-DOLS); Developing countries.

\subsection{Introduction}

Developing countries look at FDI and the location of MNC's as an engine of growth. These international investments will benefit to a host country in terms of capital inflows, employment, new technology, management skills, and most importantly Research and Development (R\&D) spillover that will encourage innovation in the host country.
UNCTAD (2008), FDI and MNC's in developing countries plays a major role in the internationalization of $\mathrm{R} \& \mathrm{D}$ activities. More than $95 \%$ of the 700 firms worldwide with the largest $R \& D$ expenditure are from MNCs. In order to attract the MNC's to invest in the R\&D, host countries itself must present the location advantages. UNCTAD (2005) state that developing countries, especially in Asia and the Pacific that have a good infrastructure, attractive 
domestic market, highly trained workforces and reasonable intellectual property protection will attract the significant FDI in R\&D. Host countries will benefit from the opportunities that provided and only increase the demand of MNC's for inexpensive talent and for new developing markets. Host countries will focus to maximize the technology spillovers from FDI and will encourage them to engage in $R \& D$ activities. So there exist the relationship between the countries that actively involved in $R \& D$ activities and countries that shown the significant economic improvement. To catch up with the developed countries, it is essential for countries either developing or least developed countries to build $\mathrm{R} \& \mathrm{D}$ capacities to upgrade their technology. R\&D activities represent the most privileged method by which companies generate and acquire technological information. For the decades, R\&D is the only factor that has driven the technology change and innovation that be an important sources for the country productivity growth. The R\&D intensive FDI is expected to bring significant benefit to host countries that will associate with a net increase in host country $R \& D$ activity that involving more $R \& D$ expenditure and create the job opportunities for highly skill labor. These benefits will be larger when the $R \& D$ investment by MNC's complements the R\&D at host countries. To encourage more benefit from FDI and MNC, host countries should have a good institution that can refer to especially the level of economic freedom. The level of economic freedom is very important in explaining the inflows of FDI (Pejovich 2002).

The concepts of economic freedom can be defined separately based on individual, society and the economy itself. From the individual view, in economically free, the individual can control their productivity based on labor and initiative, which is an individual has empowered to decide where to live and work and at the same time, they have the right to own property and dispose of it as they choose. Succeed and fail individuals based on the effort and ability. The concept of freedom on government view is government decision making is characterized by transparency and openness, and the light of opportunity replaces the shadows where discrimination can be more subtle. Besides that, in an economically free, the power of economic decision making is widely dispersed, and the allocation of resources for production and consumption is on the basis of free and open competition so that every individual or firm has a fair chance to succeed. A country that provides for economic freedom allows for greater diversity, promoting creativity, encourages new technology and innovation that impact on country economic growth. The relationship between growth and economic freedom is in one direction, which is the increase in the rating of economic freedom will enhance the economic growth, but there is no tendency for higher economic growth to increase the economic freedom. Previously, numerous researchers have studied these relationships and found that countries with higher and improving economic freedom grew more rapidly and achieve higher levels of per capita GDP. According to James and Lawson (2008), countries with a large amount economics freedom grew significantly quicker than others, while those with the least economic freedoms experienced negative growth.

Economic freedom is the main key to overall economic well-being. Countries that enjoy higher levels of economic freedom should be more attractive for foreign investors. The link between economic freedom and growth is then strengthened, since economic freedom affects growth through two channels: directly (De Haan and Sturm, (2000)) and indirectly (i.e. By facilitating of FDI that, in turn, fosters economic growth). Countries with the economically free increase 50 percent to the productivity investment. Countries with an economic freedom index rating more than 7.0 (based on the Fraser index) shows with a 1 percent increase in investment to expand output by 0.35 percent and on the other side countries with economic freedom index less than 5.0 only contribute 0.23 percent increase in output. So, there is highly supportive of the proposition that countries or institutions that consistence with economic freedom will lead to the higher rate of investment and at the same time will contribute to the greater productivity of the investment.

\subsection{Research Issues}

For many years, researchers have debated about the economic growth and total factor productivity. Among the key factors of growth 
and productivity are the level FDI. FDI is believed to have beneficial effects on economic growth in the host country due to advantages related to the introduction of new technologies and innovation, new managerial techniques, development of additional skills, increased capital, job creation and improvement of working conditions, improving the human capital, the development of the industrial sector in the host country, broadening of the tax base transfer of the technology and other skills, boosting the economic activity, boosting of export, better integration into the world markets and etc. (Perez 1997; Haddad and Harrison 1993; Markusen and Venables 1999; Babic and Strucka (2001). Besides knowing whether the market is a growing market, investors will look also at the host countries, institutional as factor to make the investment decision. An institution can be viewed as a social structure element of a country which has been instituted by law or customs. Since the 1990s, the importance of institutional quality has been highlighted and found to be very pertinent in addressing issues of growth and FDI with the literature by North (1990) and Williamson (2000). IMF (2003), quality institutions, and the rules of the game in a country are defined in terms of the degree of property rights protection, the degree to which laws and regulations are fairly applied and the extent of corruption. Civil liberties, organization rights, freedom of association and the freedom of expression, the rule of law and human rights, are all important influences on business decision-making. 'Good' institutions are an important determinant, or precondition for, economic growth and development. An institution can be referred to freedom, whether economic, political or civil freedom that apply to the economy. Dawson (1998), in fact institutions affect aggregate economic activity indirectly through an effect on investment or directly through an effect on total factor productivity. Institutions that undertaking economic freedom probably has the capacity to provide the growthenhancing kind of incentives, for several reasons; as argued in Murphy et al. (1991), they promote a high return on productive efforts through low taxation, an independent legal system, and the protection of private property and Johansson (2001) they promote the flow of trade and capital investment. Pejovich (2002), the level of economic freedom is very important in explaining the inflows of FDI. The higher the level of economic freedom of the country will attract more inflows of FDI. R\&D spillover does not limit in the specific country, but can cross all the borders. Romer (1986) allows companies to invest in $\mathrm{R} \& \mathrm{D}$ with the condition that marginal profitability equal to innovation cost. According to Bart (1997) the estimated rates of return for $\mathrm{R} \& \mathrm{D}$ investment, considered to be the major input in technology generation. For many years people have debated about the role of economic freedom on FDI and economic growth and R\&D effect on productivity. The intention of this dissertation is to establish the purpose for which of the role of economic freedom, which particular reference to whether they are using in mediating the domestic and foreign R\&D and further, to gather ideas to expand the country productivity.

The main research questions arise here is does economic freedom play a significant role in mediating R\&D spillover on TFP growth?. To answer question that arises in this study, we analyze the role of economic freedom in mediating $\mathrm{R} \& \mathrm{D}$ spillovers on total factor productivity. Based on the goal of this study, we proposed conceptual framework that diagrammatically reflects the intention.

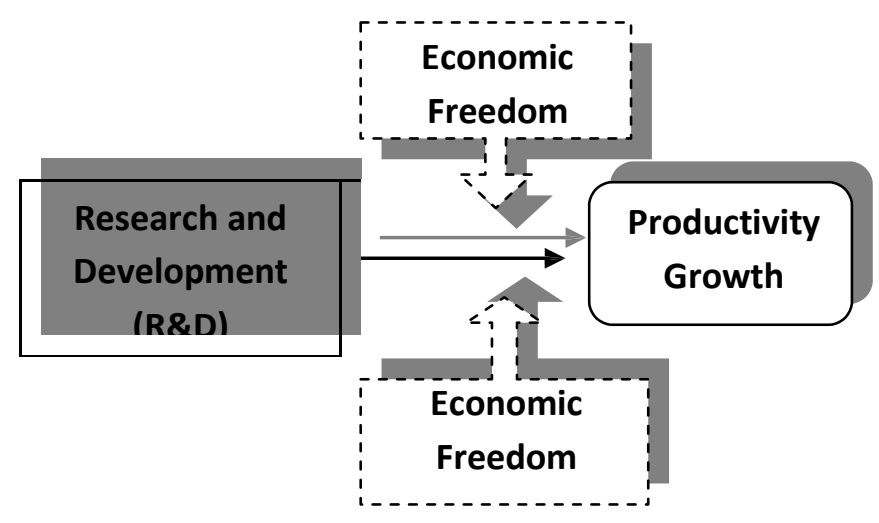

Figure 1: The Conceptual framework

\subsection{Significant of the study.}

This study contributes to the literature by providing the empirical evidence on the significant role of economics in mediating the impact of domestic and foreign $R \& D$ on the productivity growth. Panel dynamic ordinary least square (P-DOLS) analysis is a better way to understanding the relationship between the economic freedom and domestic and foreign $\mathrm{R} \& \mathrm{D}$ and it can accommodate the meaningful 
possibility that both domestic and foreign $R \& D$ kick in country productivity growth only after including the economic freedom as a mediating factor.

\subsection{Organization of study.}

The rest of the paper is structured as follow. In section 2 , we provide an overview of related empirical work on domestic and foreign R\&D, FDI, economic freedom and TFP growth. In section 3, we describe the data set that we use and methodology to analyze. The empirical analysis is in section 4 and finally in section 5 is a conclusion and recommendation.

\subsection{Literature Review}

Many researchers state that economic freedom is an important factor for the country because it is one of the main drivers of prosperity and growth. According to economic theory, economic freedom will affects incentives, productive effort, and the effectiveness of resource use. Numerous studies state that countries with having an initial level of economic freedom will lead to the growth of that country (Ali 1997; Easton and Walker 1997; Goldsmith 1997; Dawson 1998; Wu and Davis 1999; Hanson 2000; Pitlik 2002; Scully 2002; Weede and Kamph 2002; Haan et al. (1996). McQuillan and Murphy (2009), state that the main finding in their research is that economic freedom promotes not only higher incomes, but the growth rate in output and incomes especially in developing countries. Islam (1996) indicated that economic freedom has a direct relation with per capita income and economic growth rate by using cross-section data analysis in 98 low, middle and high-income countries. On the other hand, Cole (2003) looked at 106 countries and found that economic freedom had significant explanatory power across competing theories of economic growth, where Cole looked at the factors that different group's economist believed are important for economic growth and showed that adding the factor economic freedom shed more light on which countries grow faster that others.

Gwartney et al. (1996), that develop the measurement of economic freedom in Fraser Institute's, note that the countries with the highest economic freedom scores have an average annual growth rate of per capita real GDP, while those with the lowest economic freedom scores have an average negative growth rate per capita real GDP. This supported by the Holcombe and Gwartney (2010), Gwartney and Lawson (2005), Berggren (2003), countries that have more economic freedom have on average higher per capita incomes and countries that increase their economic freedom exhibit higher rates of economic growth, which is the level of economic freedom can be seen when countries have lower unemployment rates, lower percentages of children in labor forces, higher life expectancies and more political freedom. Depken and Sonara (2005), investigate the impact of economic freedom and trade flows by estimating a gravity model using the freedom index developed by the Fraser Institute and find that higher level of economic freedom is strongly correlated with increased trade flows. Calvo and Robles (2003) explore the economic freedom and FDI flows and found that greater economic freedom in host country increases FDI inflows in the 18 Latin American countries. They also postulate that FDI is also positively correlated with economic growth in the host country with the adequate human capital, liberalized markets and economic stability to promote from long term capital flow. Pourshahabi et al. (2011) supported this finding by indicating that economic freedom in OECD countries has positive and non significant effect on FDI and consistence with theoretical expectation and according to them it is not significant because there is not any large economic freedom gap between these sets of countries that can lead to significant differences of FDI. Hanke and Walters (2000), development cannot achieve its goals without economic freedom because economic freedom can fuel economic growth and spur growth. Berggren (2003), shows the clear about this complexity of economic freedom, by saying that some EFI components causing growth, some EFI components being caused by growth, and some EFI components being jointly determined with growth.

Doing $\mathrm{R} \& \mathrm{D}$ is important for productivity and also economic growth. Domestic R\&D has high spillover effects, it enhances the ability of the business sector to absorb technology coming from abroad. R\&D spillover does not limit in the 
specific country, but can cross all the borders. Romer (1986) allows companies to invest in $\mathrm{R} \& \mathrm{D}$ with the condition that marginal profitability equal to innovation cost. According to Bart (1997) that although the significance of the spillover effects is beyond doubt, the estimated rates of return to $R \& D$ investment, considered being the major input in technology generation, vary over a large range. Researchers also discuss the role of foreign $R \& D$ and domestic $R \& D$ in influencing the host country productivity. A number of studies for developing countries document that a foreign presence promotes higher productivity in host country sectors, while other studies point to limited or no significant efficiency spillovers. Lichtenberg and Van Pottelsberghe (1998) show that foreign $\mathrm{R} \& \mathrm{D}$ can affect domestic performance through both imports and outward FDI that is through technology sourcing and learning practices. Coe and Helpman (1985), found a significant contribution of foreign $R \& D$ on the total factor productivity in 22 industrialized countries. They found in smaller countries, the effects of foreign $\mathrm{R} \& \mathrm{D}$ capital are as a big as those domestic $\mathrm{R} \& \mathrm{D}$, while in the larger countries, domestic R\&D play a crucial role rather than foreign R\&D.

An economist who argues that economic freedom is a key ingredient for economic growth process fall in the institutional views. According to Powell (2003), the degree of economic freedom either hinders or helps in achieving economic growth is supported by the key institutional factor. The institutional which stresses the importance of creating an institutional and policy environment conducive for smooth operation of markets and realization of gains from trade and entrepreneurs activity (North, 1990; Hayek 1945, 1960). The other view by Berggrren (2003), economic growth will boost if the institutions itself guarantee the economic freedom by promote capital investment where returns are highest, facilitate predictable and rational decision making through a low and stable inflation rate, by foster a dynamic economy in which competition can occur because regulations are few, enable talents to be located to where it generate the highest value, and promote high return through low taxation, sound legal system and protection of private property. Gwartney et al. (1999) postulate that an economy with higher economic freedom can make the market operate well through offering the well-defined rule of trade and securing property rights. The strongest protection of private property and a well functioning judicial system are the most importance of various institutions and policy variables for economic growth without consider to the economic freedom index (Torstensson 1994; Goldsmith 1995; Barro 1997,1999; Nelson and Singh 1998; Norton 1998a; Hall and Jones 1999; Keefer 1999; Kneller, Bleaney and Gemmell 1999; Olson, Sarna and Swamy 2000; Vijayaraghavan and Ward 2001; Feld and Voight 2000).

\subsection{Methodology}

\subsection{Introduction}

This section comprises the discussion regarding the estimation model, data and econometric methodology that will be built and used to test the role of economic freedom in mediating $R \& D$ spillovers on total factor productivity. The econometric model designed is a total factor productivity (TFP) model, based on the extension of Mansfield (1984) model. The Dynamic Ordinary Least Square (DOLS) test is conducted, to test the long run and cointegration relationship between the variables.

\subsection{Empirical Model specification}

To analyze the role of economic freedom in mediating the R\&D spillovers, the econometric model can be expressed as an equation (1) of domestic R\&D and the equation (2) of foreign R\&D. (1)

$$
\begin{aligned}
& L T F P_{i t}=\alpha+\beta_{1} L D R D_{i t}+\beta_{2} L D R D E F_{i t}+\varepsilon_{i t} \\
& L T F P_{i t}=\alpha+\beta_{3} L F R D_{i t}+\beta_{4} L F R D E F_{i t}+\varepsilon_{i t}
\end{aligned}
$$

Where $i$ is a developing country and $t$ is the time index. TFP is total factor productivity, DRD is domestic $R \& D, \quad$ is foreign $R \& D$, $\mathrm{EF}$ is index of economic freedom. In order to estimate the role of economic freedom in mediating R\&D spillover, the interaction term will be used by DRDxEF and FRDxEF, whereas the interaction term is given by EF, DRD and FRD to ensure that the interaction term does not proxy for economic freedom or domestic $R \& D$ 
and foreign $\mathrm{R} \& \mathrm{D}$, because these variables also include in the regression model. All variables are in logarithmic form. is country specific intercept, is the elasticity of TFP respect to domestic R\&D, is the elasticity of TFP respect to interaction term of domestic $R \& D$, is the elasticity TFP respect to foreign $R \& D$ and economic freedom, is the elasticity TFP respect to interaction term of foreign $R \& D$ and economic freedom and is the random error term.

\subsection{Long-run elasticities: Stock-Watson Dynamic OLS}

One method that proposed by Stock and Watson (1993) in estimation, long run equilibria is dynamic OLS (DOLS). This method corrects for possible simultaneity bias among the regressors. Besides that, this method suggests a parametric approach for estimating long run equilibria in a system which may involve variables integrated of different orders but still cointegrated. The procedure advocated is similar to recent estimators proposed by Phillips and Loretan (1991) and Saikkonen (1991), but is much more practically convenient to implement and estimate. Stock and Watson DOLS parameter estimates of the long run parameters with all variables appearing in levels, along with their approximate asymptotic standard errors. Equation (3) and (4) examine the long run estimation of domestic $R \& D$ with foreign $R \& D$ and interaction between economic freedom with domestic R\&D and foreign R\&D.

$$
\begin{aligned}
& \text { LTFP }_{t}=\alpha+\beta_{1} \text { LDRD }_{t}+\beta_{2} \text { LDRDEF }_{t} \\
& +\sum_{j=-p}^{p} \delta_{1} \Delta \ln T F P_{t-j}+\sum_{j=-p}^{p} \delta_{2} \triangle L D R D_{t-j} \\
& +\sum_{j=-p}^{p} \delta_{3} L D R D E F_{t-j}+\varepsilon_{t} \\
& \operatorname{LTFP}_{t}=\alpha+\beta_{1} \text { LFRDFDI }_{t}+\beta_{2} \text { LFRDEF }_{t} \\
& +\sum_{j=-p}^{p} \delta_{1} \Delta \ln T F P_{t-j}+\sum_{j=-p}^{p} \delta_{2} \Delta L F R D_{t-j} \\
& +\sum_{j=-p}^{p} \delta_{3} L_{F R D E F_{t-j}}+\varepsilon_{t}
\end{aligned}
$$

\subsection{Short-run elasticities: Error Correction Term (ECT)}

For short run estimation, we used error correction term estimates of all models in this study. According to Hendry's (1995), ECT is general to specific modeling approach that used to derive a satisfactory short run dynamic model. The value of ECT indicates the evaluation process on the variable concern by which adjusts for prediction errors made in the last periods. The regression results for the short run equations show several desirable statistical features. The coefficient of ECT measures the speed of adjustment back to the long run equilibrium value, and negative value of ECT indicates that the error correction mechanism exist in the model. The literature postulates that the coefficient of the lagged error correction term should be negative and statistically significant to further confirm the existence of a long-run relationship.

$$
\begin{aligned}
& \Delta \ln T F P_{t}=\alpha_{1}-\lambda_{t} E C T_{t-1}+\sum_{i=1}^{p-1} \beta_{1, t} \Delta \ln T F P_{t-i}+ \\
& \sum_{i=0}^{q-l} \beta_{2, t} \Delta L D R D_{t-i}+\sum_{i=0}^{r-1} \beta_{3, t} \Delta L D R D E F_{t-i}+\varepsilon_{t}
\end{aligned}
$$

$\Delta \ln T F P_{t}=\alpha_{1}-\lambda_{t} E C T_{t-1}+\sum_{i=1}^{p-1} \beta_{1, t} \Delta \ln T F P_{t-i}+$ $\sum_{i=0}^{q-t} \beta_{2, t} \Delta L F R D_{t-i}+\sum_{i=0}^{r-1} \beta_{3, t} \Delta L F R D E F_{t-i}+\varepsilon_{t}$

\subsection{Data set}

The data set consists of panel data observation of 37 selected developing countries over the $2000-2010$ periods. Where we classify developing countries based on income level of high income countries, middle income countries, lower middle income countries and low income countries to examine the role of economic freedom in mediating the impact of $R \& D$ on productivity growth (list of countries in Appendix 1). Variable that we used in this study are total factor productivity (TFP), economic freedom (EF), domestic R\&D and foreign $R \& D$. Where TFP measure based on Klenow and Rodriguez (1997) specification; economic freedom based on the Fraser index developed by Gwartney et al. (1996) (Appendix II); domestic $R \& D$ based on $R \& D$ capital stocks were calculated using the perpetual inventory procedure and foreign R\&D based on the inward FDI weighted foreign $R \& D$ capital stock following Van Pottelsberghe and Lichtenberg (2001).

\subsection{Result and Discussion}

\subsection{Introduction}

This section will discuss the empirical result of the role of economic freedom in mediating 
research and development (R\&D) on productivity growth based on discussions in section 3. The methodologies that we used to examine the role of economic freedom are panel dynamic OLS (DOLS) proposed by Stock and Watson (1993) and supported basic test of unit root test of ADF and PP test and we estimate error correction term to support the dynamic OLS test.

\subsection{Univariate integration: Test of the unit root hypothesis.}

As a necessary test for multivariate cointegration, two types of unit root test were carried out, that are Augmented Dickey Fuller test and Phillips-Perron test from now on called ADF and PP test. Both ADF and PP test based on the null hypothesis that a unit root exists in the autoregressive representation of the data variable. The results of $\mathrm{ADF}$ and $\mathrm{PP}$ tests are presented in Table 1 for income group basis for the time period 2000 to 2010. The ADF and PP test model are intercepted, intercept and trend and none are reported based on $\mathrm{p}=1, \mathrm{p}=2$ and $\mathrm{p}=3$. Table 2 presents results from two tests discussed earlier based on four groups of countries.

Table 1: Unit Root Test.

\begin{tabular}{|c|c|c|c|c|}
\hline \multirow{2}{*}{$\begin{array}{l}\text { Varia } \\
\text { ble }\end{array}$} & \multicolumn{2}{|c|}{ Level } & \multicolumn{2}{|c|}{ First Difference } \\
\hline & ADF & $\mathbf{P P}$ & ADF & $\mathbf{P P}$ \\
\hline \multicolumn{5}{|c|}{ Panel A: High Income Countries } \\
\hline LTFP & 1.36 & 0.52 & $44.52 * * *$ & $50.84 * * *$ \\
\hline LEF & 8.38 & 8.88 & $78.99 * * *$ & $77.85 * * *$ \\
\hline LDRD & 11.12 & 10.17 & $40.28 * * *$ & $30.63 * * *$ \\
\hline LFRD & 9.88 & 12.36 & $98.44 * * *$ & $102.43 * * *$ \\
\hline \multicolumn{5}{|c|}{ Panel B: Upper Middle Income countries } \\
\hline LTFP & 41.65 & $54.58 * *$ & $141.68 * * *$ & $138.46^{* *}$ \\
\hline LEF & 14.41 & 14.50 & $214.52 * * *$ & $224.44 * * *$ \\
\hline LDRD & $52.99 *$ & $64.52 * * *$ & $176.35 * * *$ & $178.90 * * *$ \\
\hline \multicolumn{5}{|c|}{ Panel C: Lower Middle income countries } \\
\hline LTFP & 7.32 & 7.21 & $73.35 * * *$ & $67.20 * * *$ \\
\hline LEF & 6.15 & 6.89 & $80.26 * * *$ & $83.91 * * *$ \\
\hline LDRD & $35.26 * * *$ & $32.13 * * *$ & $116.44 * * *$ & $121.01 * * *$ \\
\hline LFRD & 16.54 & 24.32 & $93.28 * * *$ & $92.96 * * *$ \\
\hline LTFP & $22.11 * * *$ & $25.56 * * *$ & 7.06 & 7.05 \\
\hline LEF & 0.64 & 0.20 & $34.51 * * *$ & $34.51 * * *$ \\
\hline LDRD & 6.71 & 7.32 & $8.58 * *$ & $8.11 * *$ \\
\hline LFRD & $9.50 * *$ & $26.12 * * *$ & $18.49 * * *$ & $18.32 * * *$ \\
\hline \multicolumn{5}{|c|}{$\begin{array}{l}\text { Notes: Ho: Unit root process for } \mathrm{ADF} \text { and PP. } * * *, * * \\
\text { and } * \text { indicate significance at the } 1,5 \text { and } 10 \% \text { levels. } \\
\text { Optimal lag lengths in ADF and PP were selected based } \\
\text { on AIC. }\end{array}$} \\
\hline
\end{tabular}


domestic $R \& D$ and at the same time supportive of increasing in national TFP.

On the other hand, estimation results of foreign $R \& D$ show that based on income group results, Panel A of high income, Panel $\mathrm{C}$ of lower middle income and Panel D for low income show the opposite sign with full sample that indicate economic freedom played an important role in mediating FRDFDI on TFP except for Panel B of upper middle income that results are same as full sample of developing countries. We can conclude that since the level of economic freedom for the income groups are different, so there has difference in the role of economic freedom on foreign $R \& D$ based on FDI spillovers. Based on Berstein (1994) and Berstain and Yan (1995) that state the importance of foreign $\mathrm{R} \& \mathrm{D}$ on country productivity, but when we integrate with economic freedom this result will be more essential to the country's productivity.

\subsection{Result of Short-run elasticities: Error Correction Term (ECT)}

For short run estimation, we used error correction term estimates of all models in this study. According to Hendry's (1995), ECT is general to specific modeling approach that used to derive a satisfactory short run dynamic model. The value of ECT indicates the evaluation process on the variable concern by which adjusts Ior preaiction errors made in tne last perioas. The regression results for the short run equations show several desirable statistical features. The coefficient of ECT measures the speed of adjustment back to the long run equilibrium value, and negative value of ECT indicates that the error correction mechanism exist in the model. The literature postulates that the coefficient of the lagged error correction term should be negative and statistically significant to further confirm the existence of a long-run relationship.

Analysis of domestic R\&D indicates that for high income, both variables indicate negatively related with TFP. However upper middle income countries and low income countries indicate the importance of economic freedom in mediating the impact of domestic R\&D on TFP. Results of short-run for this model are totally different with results of long-run estimated by dynamic OLS that discuss previously, where to long run economic freedom are important in mediating the impact of domestic R\&D on TFP except for upper middle income countries. We can conclude that, economic freedom plays an important role in the long run not in short as a mediator of domestic R\&D.

Results of foreign $\mathrm{R} \& \mathrm{D}$ showed that the ECT value of all panels is negative and statistically significant, indicate that this model has a long run relationship. Based on reported results, economic freedom plays an important role in mediating the impact of foreign $R \& D$ based on the FDI channel except for panel $\mathrm{C}$ of upper middle income that point out TFP are positively related to foreign $R \& D$ without economic freedom as a mediator variable.

These short-run results are consistent with the long run estimation of dynamic OLS, which economic freedom is important as a mediator variable of foreign $\mathrm{R} \& \mathrm{D}$ for FDI channels in influence TFP in developing countries.

Table 3: Result of Short run dynamics OLS

\begin{tabular}{|c|c|c|c|c|}
\hline & Panel A & Panel B & Panel C & Panel D \\
\hline \multicolumn{5}{|c|}{ Domestic R \&D } \\
\hline ECT & -0.32 & $0.13 * * *$ & $-0.36 * * *$ & $-0.11 * * *$ \\
\hline LDRD & -0.30 & -0.17 & 0.06 & -1.32 \\
\hline LDRDEF & -0.003 & 0.02 & -0.007 & 0.22 \\
\hline \multicolumn{5}{|c|}{ Foreign R\&D } \\
\hline$\overline{\mathrm{ECT}}$ & $-0.34 * * *$ & $-0.18 * * *$ & $-0.43 * *$ & $-0.54 * * *$ \\
\hline FRD & -0.13 & 0.0007 & -0.009 & -0.49 \\
\hline FRDEF & 0.09 & -0.001 & 0.001 & 0.42 \\
\hline
\end{tabular}

Note: $* * *, * *$ and $*$ indicate significance at the 1,5 and $10 \%$ levels, Panel A: High Income Countries; Panel B: Upper Middle Income Countries; Panel C: Lower Middle Income Countries; Panel D: Low Income Countries

\section{Conclusion}

This study investigates the role of economic freedom in mediating the impact of domestic $\mathrm{R} \& \mathrm{D}$ and foreign $\mathrm{R} \& \mathrm{D}$ of 38 developing countries over the period 2000 to 2010. First, we carry out panel unit root tests to ensure that all panel variables are integrated of order 1 . Visual inspection of the data reveals that the variables seem to follow a common trend over time so that we include constant and trend terms and none in the panel unit root and integration tests. 
Fisher- $A D F$ and Fisher- $P P$ panel unit root tests are employed and we have found that the variables are mixed of stationary and nonstationary in levels. After first-differencing the variables, all of the tests reject the null of nonstationarity. It implies that the first-differenced variables come from a stationary process where the means and variances are constant over time.

This dynamic panel data model we estimate for long runs of dynamic OLS and short run of error correction term tests. Empirical results show that economic freedom plays an important role in mediating the impact of domestic $R \& D$ in the long run but not in short. On the other hand, results for foreign $\mathrm{R} \& \mathrm{D}$ indicate that economic freedom is important as a mediator variable of foreign R\&D for FDI channels in influence TFP in developing countries in the short run and long run period. Thus we can conclude that economic freedom is an important factor in encouraging the development of $R \& D$ in developing countries.

Economic environments that conducive and provide for economic freedom will allows greater diversity, promoting creativity, encourage new technology and innovation. Policy marker and government should provide or formulate policy and ready to reduce their intervention to ensure that country is freer because economic freedom is one of the main drivers of prosperity and growth. On the other hand, government and policy makers should develop policy that provides the best environment for domestic firm and foreign firm do business and trade. In other words, less regulation of trade, open the economy, flexible labor market, more developed stock market and financial market that will encourage more inflows of FDI and the location of MNC's where they will bring along a new technology that will encourage $R \& D$ activities that will boost country productivity.

\section{References}

Acs,Z.J., Braunerhjelm, P., Audretsch, D. B., \& Carlsson, B. (2009). The knowledge spillover theory of entrepreneurship. Small Business Economics. 32(1), 15-30
Aghion, P. \& Howitt. P., (1992). A Model of Growth Through Creative Destruction. Econometrica, 60, 323-351

Ali, A., (1997). Economic Freedom, Democracy and Growth. Journal of private enterprise 13. (fall): 1-20

Barro,R.J 1997. Determinant of economic growth; A Cross Country Emperical Study, Cambridge, Mass: MIT Press

Barro,R.J., (1999). Inequality, Growth, and Investment. Working Paper no.w7038. Cambridge Mass: National Bureau of Economic Research.

Belderbos, R., Carree, M., \& Lokshin, B. (2006). Complementarity in R\&D cooperation strategies. Review of Industrial Organization 28, 401-426.

Berggren, N. (2003). The Benefit of Economic Freedom: A Survey. Independent Review 8(2): 193-211

Bernstein,J,. (1994). International R\&D spillover between Industries in Canada and United States. Industry Canada working Paper series No.3

Bernstein,J,. \& Xiaoyi Y., (1995). International $\mathrm{R} \& \mathrm{D}$ spillover between Industries in Canada and Japanese Industries. NBER working Paper series No.5401

Calvo.M.B \& Robles.B.S, (2003). Foreign Direct Investment, Economic Freedom, and Growth: New Evidence from Latin America. European Journal of Political Economy 19, no. 3 (2003), pp. 529-45.

Coe, D., \& Helpman, E., (1995). International R\&D Spillovers. European Economic Review, 39, pp. 859-887.

Coe, D \& Helpman, E. (1993). International R\&D Spillovers. National Buraeu of Economic Research Working Paper, Cambridge, MA, No. 4444, August 1993.

Coe,D.T. \& Helpman, E., (1995). International R\&D Spillover. NBER Working Paper. No. 5048.

Cohen, Wesley M. \& Klepper,S., (1991). Firm Size versus Diversity in the Achievement of Technological Advance.

Cohen, W. M. \& Klepper, S., (1992). The Tradeoff between Firm Size and Diversity in the Pursuit of Technological Progress. Small Business Economics, 4(1), 1-14.

Cohen, W. M. \& S. Klepper (1996a). Firm size and the nature of innovation within 
industries: the case of process and product R\&D. Review of Economics \& Statistics, 78(2), 232-243.

Cohen, W.M., \& Richard C. Levin (1989 )"Empirical studies of innovation and market structure. In R. C. Schmalensee and R. Willig (eds.), Handbook of Industrial Organization: 1059-1 107. Amsterdam: Elsevier. UNCTAD 2000

Cole.J.H,(2003). The Contribution of Economic Freedom to World Economic Growth: 1980-99. Cato Journal 23, no. 2 (fall 2003), pp. 189-99.

Dawson, J. W. (1998). Institutions, Investments and growth: New cross country and panel data evidence. Economic Inquiry 36 (October): 603-19

De Haan, J., Lundstrom, S. \& Sturm. J. (2006). "Market-Oriented Institutions and Policies and Economic Growth: A Critical Survey," Journal of Economic Surveys, 20(2): 157-191

De Haan, Jakob \& Sturm, J.E, (2000). On the relationship between economic freedom and economic growth. European Journal of Political Economy 16: 215-241.

Depken C. A. \& Sonara. R.J (2005) The asymmetric effects of economic freedom on International Trade Flows. Journal Economic Literature (F14, R10)

Easton, Steven T., Micheal A. Walker. (1997). Income, Growth and Economic Freedom. American Economic review 87, no. 2:328-32.

Erken, H.; Donselaar, P.; \& Thurik, R (2008) Total factor productivity and the role of entrepreneurship. The JENA Economic Research Papers

Feld,L.P., and Voight.S. (2002). Economic growth and rule of law. Cross Country Evidence using a new set of indicators. Paper presented to the public Choice Society, San Diego, march 22.

Fors, G., (1996)Utilization of R\&D, results in home and foreign plants of multinationals, Journal of Industrial Economics, 45,3, 341-345

Goldsmith, A.A (1995). Democracy, Property rights and growth. Journal of Dvelopment Studies 32,no.2; 157-154

Goldsmith, Arthur A. (1995). Economic Rights and Government in Developing Countries: Cross National Evidence on
Growth and Development. Studies in Comparative International Development 32, no.2:29-44.

Griliches, Z.: (1979). Issues in assessing the contribution of research and development to pro- productivity growth. Bell Journal of Economics I0 (1), 92-116.

Griliches, Z. \& Lichtenberg, F, (1984). R\&D and Productivity Growth at Industry Level: Is there still a Relationship?, in: Z. Griliches (ed.), R\&D, Patents and Productivity, Chicago, University of Chicago Press.

Grossman G., \& Helpman E. (1991): Innovation and Growth in the Global Economy, MIT Press, Cambridge MA.

Gwartney \& Lawson (2005) Gwartney,J. and Lawson, R. (2005). Economic Freedom of the world; 2005 Annual report. Vancouver,BC.; The Fraser Institute.

Gwartney,J. \& Lawson, R. and Block Walter (1996). Economic Freedom of the world; 1975-1995 Annual report. Vancouver,BC.; Fraser Institute

Haddad, M. and A. Harrison (1993). "Are there positive spillovers from direct foreign investment? Evidence form panel data for Morocco", Journal of Development Economics, 42: 51-74.

Hall.R.E., \& Charles,J.J., (1999). Why Do some countries Produce So Much More Output than Others?. Quarterly Journal of Economics 114, no.1;83-116.

Hanson, J.R. (2000). Prosperity and Economic Freedom. The Independent Review 4, no.4:525-531

Hayek, F. A. (1945). The Use of Knowledge in Society." American Economic Review 35, 4 (September): 519-30.

Hayek, Friedrich A. (1960). The Constitution of Liberty. Chicago, IL: University of Chicago Press.

Hendry, D. F. (1995). Dynamic Econometrics.

Oxford: Oxford University Press. Holcombe.R.G \& Gwartney.J.D (2010). Unions, Economic Freedom and Growth. Sato Journal Vol 30, No. 1 (Winter 2010)

Islam, S. (1996). Economic freedom, per capita income and economic growth. Applied Economic Letters, 3, 595-597.

Keefer,P. (1999). Does one fit All? Fitting Economic reforms to Political Institutions. Journal For Institutional 
Innovation, Development and Transition 3(March):5-14.

Kneller.R.,Micheal.F.B., \& Norman.G., (1999.) Fiscal Policy and Growth. Evidence from OECD countries. Journal of Public Economics 74, no.2:171-90

Lichtenberg, F. \& B. Van Pottelsberghe De La Potterie (1998). International R\&D spillovers: a comment. The European Economic Review 42(8), pp. 1483-1491.

McQuillan ,L.J \& Murphy.R.P. (2009). The Sizzle of Economic Freedom: How Economic Freedom Helps You and Why You Should Demand More. January 2009. Pacific Research Institute.

Nelson.M.A., \& Singh.R.D.,(1998). Democracy, Economic Freedom, Fiscal Policy and Growth in LDC's: A Fresh Look. Economic Development and Cultural Change 46, no.4: 677-96.

North, D.C., (1990). Institutions, Institutional Change, and Economic Performance Cambridge: Cambridge University Press.

Norton.S.W., (1998a). Poverty,Property and Human Well Being: A Cross- National Study. Cato Journal 18, no.2: 233-246.

Olson, Mancur, Naveen, S., \& Annad V. Swamy. (2000). Governance and Growth. A Simple Hypothesis Explaining Cross Country Differences in Productivity Growth. Public Choice 102,nos.3-4;341-364.

Oxford Bulletin of Economics and Statistics 61, 653-670.

Ptilik, Hans. (2002). The Path of Liberalization and Economic Growth. Kyklos 55, no.1:57-80.

Pourshahabi.F., Mahmoudinia.D

$\&$ Soderjani.E.S. (2011). FDI, Human Capital, Economic Freedom and Growth in OECD Countries. Research Journal of International Studies - Issue 19 (June., 2011)

Powell.B., (2003). Economic Freedom and Growth. The Case of The Celtic Tiger. Cato Journal, Vol 22., No3, Winter, pp. 431-448.

Romer P. (1986), Increasing returns and long run growth, Journal of Political Economy, 94, pp.1002-1037.

Romer P. (1990). Endogenous Technological Change, Journal of Political Economy, 98, S71-S102.
Scully, G., (2002). Economic Freedom, Government Policy and the trade Off between Equity and Economic Growth. Public Choice 113. 77-96.

Torstensson.J., (1994). Property Rights and Economic Growth: An Empirical Study. Kyklos 47,no.2:231-247.

Vijayaraghavan,Maya, \& William.A.W. (2001. I)nstitution and Economic growth: Emperical Evidence for Cross National Analysis. working paper no. 001302. Clemson,S.C; Centre of International Trade, Clemsom University.

Weede, E., \& Kampf, S., (2002.) The Impact of Intelligence and Institutional improvement on economic growth. Kyklos 55, no.3:361-380.

Williamson.C.R \& Mathers.R.L (2010). Economic Freedom, Culture, and Growth. Journal Economic Literature vol. 43. 


\section{Appendix}

\section{Appendix I}

\begin{tabular}{|c|c|}
\hline Hong Kong SAR, China ${ }^{1}$ & Panama $^{2}$ \\
\hline Iceland $^{1}$ & Peru $^{2}$ \\
\hline Israel $^{1}$ & South Africa $^{2}$ \\
\hline Kuwait $^{\perp}$ & 'I'hailand ${ }^{-}$ \\
\hline Singapore $^{1}$ & Tunisia $^{2}$ \\
\hline Trinidad and Tobago $^{1}$ & Turkey $^{2}$ \\
\hline Korea, Rep. ${ }^{1}$ & Uruguay $^{2}$ \\
\hline Algeria $^{2}$ & Bolivia $^{3}$ \\
\hline Argentina $^{2}$ & Egypt, Arab Rep. ${ }^{3}$ \\
\hline Brazil $^{2}$ & Guatemala $^{3}$ \\
\hline Chile $^{2}$ & India $^{3}$ \\
\hline China $^{2}$ & Morocco $^{3}$ \\
\hline Colombia $^{2}$ & Pakistan $^{3}$ \\
\hline Costa Rica $^{2}$ & Paraguay $^{3}$ \\
\hline Ecuador $^{2}$ & Philippines $^{3}$ \\
\hline Iran, Islamic Rep. ${ }^{2}$ & Burkina Faso ${ }^{4}$ \\
\hline Malaysia $^{2}$ & Madagascar $^{4}$ \\
\hline Mauritius $^{2}$ & Uganda $^{4}$ \\
\hline Mexico $^{2}$ & \\
\hline
\end{tabular}

Note: 1. High Income; 2. Upper Middle Income; 3.

Lower Middle Income; 4. Low Income

\section{Appendix II}

\section{Economic Freedom (Fraser Index)}

1. Size of Government: Expenditures, Taxes and Enterprises.

2. Legal Structure and Security of Property Rights.

3. Access to sound Money.

4. Freedom to exchange with foreigners.

5. Regulation of Credit, Labor and Business. 